\title{
External Shocks, U.S. Monetary Policy and Macroeconomic Fluctuations in Emerging Markets
}

\section{Bartosz Maćkowiak*}

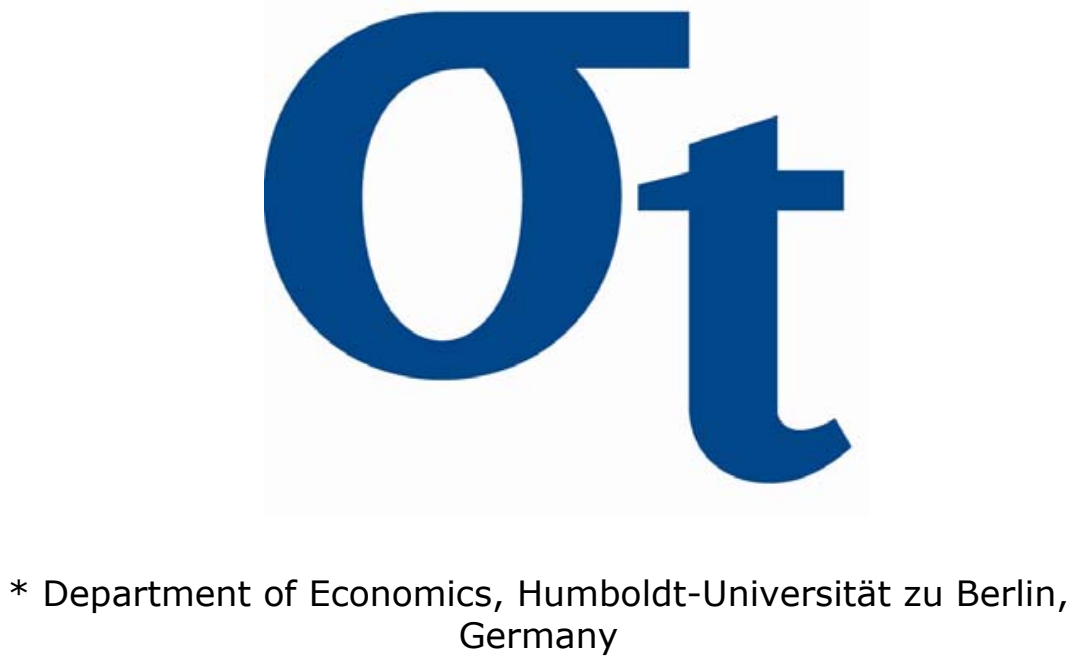

This research was supported by the Deutsche Forschungsgemeinschaft through the SFB 649 "Economic Risk". 


\title{
External shocks, U.S. monetary policy and macroeconomic fluctuations in emerging markets*
}

\author{
Bartosz Maćkowiak \\ Humboldt University Berlin
}

Revised April 2006

\begin{abstract}
Using structural VARs, I find that external shocks are an important source of macroeconomic fluctuations in emerging markets. Furthermore, U.S. monetary policy shocks affect quickly and strongly interest rates and the exchange rate in a typical emerging market. The price level and real output in a typical emerging market respond to U.S. monetary policy shocks by more than the price level and real output in the U.S. itself. These findings are consistent with the idea that "when the U.S. sneezes, emerging markets catch a cold." At the same time, U.S. monetary policy shocks are not important for emerging markets relative to other kinds of external shocks.
\end{abstract}

JEL: F41, E3, O11.

Keywords: Structural vector autoregression, monetary policy shocks, international spillover effects of monetary policy, external shocks, emerging markets.

\footnotetext{
*I thank for comments Bill Brainard, Fabio Canova, Giancarlo Corsetti, Linda Goldberg, Robert King, Paolo Pesenti, Hélène Rey, Albrecht Ritschl, Chris Sims, Harald Uhlig, an anonymous referee and numerous seminar participants. This research was supported by the Deutsche Forschungsgemeinschaft through the Collaborative Research Center 649 Economic Risk. Address: Department of Economics and Business Studies, Humboldt University Berlin, Spandauer Strasse 1, 10178 Berlin, Germany. Phone: +49 302093 5752. Fax: +49 302093 5934. Email: bartosz@wiwi.hu-berlin.de. URL: http://www.wiwi.hu-berlin.de/bartosz.
} 


\section{Introduction}

To what extent are macroeconomic fluctuations in emerging markets caused by external shocks? In particular, to what extent are macroeconomic fluctuations in emerging markets caused by U.S. monetary policy shocks? Are the effects of a U.S. monetary policy shock on emerging markets larger or smaller than on the U.S. itself? Is a U.S. monetary policy shock transmitted to emerging markets quickly or with delay? This paper presents empirical evidence on these questions. The goal of the paper is to establish a set of empirical regularities that can guide researchers who build models of emerging markets, policy economists with interest in emerging markets and policy economists with interest in international spillover effects of U.S. monetary policy.

The methodology is as follows. I formulate a structural vector autoregressive (VAR) model for each emerging market in my dataset. The model includes main macroeconomic variables in an emerging market, main macroeconomic variables in the United States and world commodity prices. I assume that an emerging market is a small open economy. This lets me estimate to what extent macroeconomic fluctuations in an emerging market are caused by external shocks. Furthermore, I identify U.S. monetary policy shocks following Leeper, Sims and Zha (1996). This identification approach is common in the structural VAR literature on the effects of U.S. monetary policy shocks on the U.S. itself. This implies that I estimate impulse responses of a new set of variables to the kind of shock that has been extensively studied. This facilitates interpretation of my results.

I find that external shocks are an important source of macroeconomic fluctuations in emerging markets. Furthermore, U.S. monetary policy shocks are not important for emerging markets relative to other kinds of external shocks. At the same time, my results suggest that the spillover effects of U.S. monetary policy shocks on emerging markets are sizable, in the following two ways. U.S. monetary policy shocks explain a larger fraction of the variance in the aggregate price level and real aggregate output in emerging markets than of the variance in the aggregate price level and real aggregate output in the U.S. itself. Furthermore, a U.S. monetary policy shock affects quickly and strongly the short-term interest rate and the exchange rate in a typical emerging market. If the shock represents a contraction in U.S. monetary policy, the currency of a typical emerging market depreciates 
and this induces inflation with little delay. These findings are consistent with the idea that "when the U.S. sneezes, emerging markets catch a cold."

The idea that external shocks are important for emerging markets goes back to the empirical work of Calvo, Leiderman and Reinhart (1993). They find that external shocks explain a sizable fraction of the variance in the real exchange rates in Latin America between 1988 and 1991. I consider East Asia and Latin America, more variables and a much longer sample. Furthermore, I estimate the effects of U.S. monetary policy shocks on emerging markets. Therefore my paper makes contact with the structural VAR literature on the effects of U.S. monetary policy shocks, initiated by Sims (1980). Kim (2001) presents structural VAR estimates of the effects of U.S. monetary policy shocks on the non-U.S. G-7 countries. ${ }^{1}$ An interesting difference between Kim's results and my results is that Kim does not find support for the view that the spillover effects of U.S. monetary policy shocks on the non-U.S. G-7 countries are sizable. This difference accords well with the idea that emerging markets are more vulnerable to external shocks than large and developed economies. Recently, Canova (2005) estimates the effects of U.S. monetary policy shocks on emerging markets in Latin America. Canova finds that a U.S. monetary policy shock affects quickly and strongly the interest rates in Latin America. He also finds that external shocks are an important source of macroeconomic fluctuations in Latin America. Furthermore, Canova finds that U.S. monetary policy shocks are important for Latin America relative to two other U.S. structural shocks, U.S. supply and U.S. real demand shocks. ${ }^{2}$

The next section presents the model. Section 3 discusses the results. Section 4 concludes. An appendix gives details concerning the data.

\footnotetext{
${ }^{1}$ See also Kim and Roubini (2000). Furthermore, Miniane and Rogers (2003) estimate the effects of U.S. monetary policy shocks on interest rates in developed economies and emerging markets.

${ }^{2}$ The approach to identifying U.S. monetary policy shocks in Canova (2005) is different from the approach in this paper. Canova's identification is based on sign restrictions on impulse responses.
} 


\section{The model}

Consider the following structural VAR model with block exogeneity

$$
\sum_{s=0}^{p}\left[\begin{array}{ll}
A_{11}(s) & A_{12}(s) \\
A_{21}(s) & A_{22}(s)
\end{array}\right]\left[\begin{array}{l}
y_{1}(t-s) \\
y_{2}(t-s)
\end{array}\right]=\left[\begin{array}{l}
\varepsilon_{1}(t) \\
\varepsilon_{2}(t)
\end{array}\right]
$$

where $A_{21}(s)=0$ for each $s=0,1, \ldots, p$ and $\varepsilon(t) \equiv\left[\varepsilon_{1}(t) ; \varepsilon_{2}(t)\right]$ is a Gaussian random vector satisfying $E[\varepsilon(t) \mid y(t-s), s>0]=0$ and $E\left[\varepsilon(t) \varepsilon(t)^{\prime} \mid y(t-s), s>0\right]=I$. The variable $y_{1}(t)$ is a vector of macroeconomic variables in an emerging market. The variable $y_{2}(t)$ is a vector of variables external to an emerging market. The variable $\varepsilon_{1}(t)$ is a vector of structural shocks of domestic origin. The variable $\varepsilon_{2}(t)$ is a vector of structural shocks of external origin, including the U.S. monetary policy shock. I formulate the model separately for each emerging market in my dataset. I assume that an emerging market is a small open economy. This assumption implies the block exogeneity restriction $A_{21}(s)=0$ for each $s=0,1, \ldots, p$. The block exogeneity restriction means that the domestic shocks in $\varepsilon_{1}(t)$ do not affect the external variables in $y_{2}(t)$ either contemporaneously or with lags. ${ }^{3}$ Given the block exogeneity restriction, I decompose the variation in the variable $y_{1}(t)$ into the variation caused by the domestic shocks in $\varepsilon_{1}(t)$ and the variation caused by the external shocks in $\varepsilon_{2}(t) .4$

The dataset consists of 8 emerging markets from East Asia (Hong Kong, Korea, Malaysia, Philippines, Singapore, Thailand) and Latin America (Chile and Mexico). For each emerging market the variable $y_{1}(t)$ includes a short-term interest rate, the exchange rate, ${ }^{5}$ a measure of real aggregate output and a measure of the aggregate price level. Furthermore, the variable $y_{2}(t)$ includes the Federal Funds rate, a measure of world commodity prices, a measure of the U.S. money stock, a measure of U.S. real aggregate output and a mea-

\footnotetext{
${ }^{3}$ The block exogeneity restriction is testable, since it implies that the variable $y_{2}(t)$ is Granger causally prior with respect to the variable $y_{1}(t)$ and Granger causal priority is a testable restriction. I tested the restriction that $y_{2}(t)$ is Granger causally prior with respect to $y_{1}(t)$ using the Schwarz criterion. I found that the data favored the restriction in the case of each emerging market in my dataset.

${ }^{4}$ Cushman and Zha (1997) is the first paper to use a structural VAR model with block exogeneity. See also Zha (1999).

${ }^{5}$ The exchange rate is defined as the number of units of the currency of a given emerging market per one U.S. dollar.
} 
sure of the U.S. aggregate price level. All data are monthly and in logarithm, except that interest rates are in percentage point at an annual rate. The data run from January 1986 to December 2000, except that the data for Thailand begin in January 1987. An appendix contains details of the data. ${ }^{6}$

My approach to identification of U.S. monetary policy shocks follows Leeper, Sims and Zha (1996) who use non-recursive restrictions on the contemporaneous comovement among U.S. variables. ${ }^{7}$ I assume that the Federal Funds rate, the policy variable of the Federal Reserve, can respond contemporaneously to changes in world commodity prices and the U.S. money stock. Furthermore, the Federal Funds rate can respond to changes in U.S. real output and the U.S. price level only with a delay of one month. The U.S. monetary policy shock is the only identified shock. Formally, the vector $y_{2}(t)$ is partitioned into three subvectors. The first subvector consists of the Federal Funds rate. The second subvector consists of world commodity prices and the U.S. money stock. I assume that world commodity prices and the U.S. money stock can respond contemporaneously to changes in all other variables in the vector $y_{2}(t)$. The third subvector consists of U.S. real output and the U.S. price level. I assume that U.S. real output and the U.S. price level can respond to changes in the Federal Funds rate, world commodity prices and the U.S. money stock only with a delay of one month. Given these assumptions the model is exactly identified. I follow Bayesian estimation methodology. ${ }^{8}$

\footnotetext{
${ }^{6}$ The model includes a constant term, a complete set of seasonal dummies and 13 lags, except that in the case of Thailand the model includes 12 lags.

${ }^{7}$ This identification approach is known to produce similar conclusions for the U.S. to the other common identification approach in the structural VAR literature, based on recursive restrictions. See, for example, Christiano, Eichenbaum and Evans (1999).

${ }^{8}$ Specifically, I took 1000 draws from the inverse-Wishart-normal posterior distribution of the parameters of the reduced-form VAR model. Afterwards I converted each draw to a draw from the posterior distribution of the parameters of the structural VAR model. I used the prior developed by Sims and Zha (1998). I specified a less tight prior than the benchmark specification of the modified Minnesota prior in Sims and Zha (1998).
} 


\section{The results}

Table 1 summarizes the estimates of the fraction of the variance in variables in emerging markets caused by external shocks and the estimates of the fraction of the variance in variables in emerging markets caused by U.S. monetary policy shocks. For comparison, Table 1 includes the estimates of the fraction of the variance in the Federal Funds rate, the U.S. price level and U.S. real output caused by U.S. monetary policy shocks. I find that external shocks are an important source of macroeconomic fluctuations in emerging markets. This conclusion is robust across variables and across emerging markets. In a typical emerging market, external shocks account for approximately one-half of the variation in the exchange rate and the price level, approximately two-fifth of the variation in real output and approximately one-third of the variation in the short-term interest rate.

Furthermore, I find that U.S. monetary policy shocks are not important for emerging markets relative to other kinds of external shocks. This conclusion is also robust. In a typical emerging market, U.S. monetary policy shocks account for less than 10 percent of macroeconomic fluctuations. However, in a sense the spillover effects of U.S. monetary policy shocks on emerging markets are sizable. Note that U.S. monetary policy shocks explain only a small fraction of the variance in the price level and real output in the United States. Then observe that U.S. monetary policy shocks explain a larger fraction of the variance in the price level and real output in a typical emerging market.

Table 2 summarizes the estimates of the impulse responses to a U.S. monetary policy shock one standard deviation in size. ${ }^{9}$ To begin, note that the impulse responses of the U.S. variables to a U.S. monetary policy shock are very similar to many estimates in the literature. In particular, U.S. inflation and U.S. real output respond only slowly to a U.S. monetary policy shock. See the last column in Table 2. A U.S. monetary policy shock has a maximum impact on U.S. inflation 10 months after the shock occurs and on U.S. real output 12 months after the shock occurs. However, the estimate of the size of a typical U.S. monetary policy shock is smaller than is common in the literature. Recall that my sample runs from 1986 to 2000 and is shorter than usual in work that focuses on the United States.

\footnotetext{
${ }^{9}$ I computed each impulse response of inflation reported in Table 2 by transforming the estimated impulse response of the prive level.
} 
This suggests that in the period 1986-2000 U.S. monetary policy shocks were smaller than in the entire post-war period. ${ }^{10}$

Next, consider how variables in emerging markets respond to a U.S. monetary policy shock. The short-term interest rate in a typical emerging market responds by 10 times as many basis points to a U.S. monetary policy shock compared with the Federal Funds rate. This is an economically significant response. Furthermore, approximately all of the response occurs within 6 months after the impact of the shock. The exchange rate in a typical emerging market depreciates by approximately 1.5 percent in response to a U.S. monetary policy contraction 10 basis points in size. This is also an economically significant response. Furthermore, again approximately all of the response occurs within 6 months after the impact of the shock. Inflation in a typical emerging market rises by approximately 0.1 percent in response to a U.S. monetary policy contraction 10 basis points in size. This is a larger response than the response of U.S. inflation. Furthermore, inflation in a typical emerging market responds faster than U.S. inflation. I obtain mixed results concerning the response of real output in emerging markets to a contractionary U.S. monetary policy shock. In a number of emerging markets real output tracks U.S. real output as both variables decrease with a similar delay. See the estimates for Korea, Singapore and Mexico. In other emerging markets the sign of the response of real output is ambiguous or real output increases.

A summary of the results is as follows. A U.S. monetary policy shock affects quickly and strongly the short-term interest rate and the exchange rate in a typical emerging market. If the shock represents a contraction in U.S. monetary policy, the currency in a typical emerging market depreciates and this induces inflation with little delay. An exchange rate depreciation tends to increase net exports. However, an increase in the interest rate tends to decrease consumption and investment. This can explain why the impulse responses of real output are mixed. ${ }^{11}$

\footnotetext{
${ }^{10} \mathrm{Kim}(1999)$ estimates the effects of domestic monetary policy shocks in the G-7 countries using the same variables that are in my vector $y_{2}(t)$ and the same identification. The impulse responses in Kim (1999) are very similar to the impulse responses reported here. Kim finds that the Federal Funds rate responds on impact by about 15 basis points to a U.S. monetary policy shock one standard deviation in size.

${ }^{11}$ I omitted error bands in the tables for the sake of clarity. It is important to note that the results
} 
There are some cross-country differences in the results. For example, in Chile the shortterm interest rate decreases and the currency appreciates after a contractionary U.S. monetary policy shock. Furthermore, Mexico, Hong Kong and Singapore respond to external shocks more strongly than a typical emerging market. In the case of Mexico this can be due to Mexico's proximity to the United States. In the case of Hong Kong and Singapore this can be due to the fact that both countries have had rigid exchange rate regimes. However, this can also be due to the fact that both countries are highly open and developed. Notice also that the short-term interest rates in Hong Kong and Singapore respond less than the short-term interest rate in a typical emerging market to a U.S. monetary policy shock. Again, this can be due to the rigid exchange rate regimes but can also reflect the fact that financial markets in Hong Kong and Singapore are well developed.

Hong Kong, the country with a tightly fixed exchange rate, does not clearly stand out from the other emerging markets. The conclusions that external shocks are important and U.S. monetary policy shocks are not important relative to other kinds of external shocks apply to all emerging markets, irrespective of exchange rate regime. This is similar to the finding in the literature that the choice of exchange rate regime does not affect the volatility of macroeconomic variables, except for the real exchange rate. ${ }^{12}$ Furthermore, inflation in Hong Kong rises after a contractionary U.S. monetary policy shock, as in most other emerging markets, despite the fact that the Hong Kong currency does not depreciate. This can be due to the fact that a contractionary U.S. monetary policy shock acts like an increase in the world real interest rate. In a small open economy, an increase in the world real interest rate can induce inflation in the non-traded goods sector even if the exchange rate does not change. This finding suggests that the sign of an impulse response in an open economy can be independent of the exchange rate regime.

\section{Conclusions for theory and policy}

Since the work of Mendoza (1991) researchers have used dynamic stochastic models of small open economies driven by external shocks. Recently, Neumeyer and Perri (2005) and

emphasized in the text are statistically significant.

${ }^{12}$ See, for example, Baxter and Stockman (1989) and Flood and Rose (1995). 
Uribe and Yue (2003) have used dynamic stochastic models of emerging markets driven by shocks to the external interest rate. This paper suggests that external shocks should play an important role in models of emerging markets. Furthermore, the paper suggests that changes in the external interest rate can have different effects depending on whether they reflect U.S. monetary policy shocks or systematic response of the Federal Funds rate to other kinds of shocks. As regards policy, the paper finds strong support for the view that the central question for policy in emerging markets is how to stabilize the economy in response to external shocks. Furthermore, the importance of this question is unaffected by the choice of exchange rate regime. If a country chooses to fix the exchange rate and thereby abandon independent monetary policy, the task of stabilizing the economy in response to external shocks lies squarely with fiscal policy.

\section{References}

[1] Baxter, M. and A.C. Stockman, 1989, Business cycles and the exchange rate regime: some international evidence, Journal of Monetary Economics 23, 377-400.

[2] Calvo, G., Leiderman L. and C.M. Reinhart, 1993, Capital inflows and real exchange rate appreciation in Latin America: The Role of External Factors, IMF Staff Papers 40, 108-151.

[3] Canova, F., 2005, The transmission of U.S. shocks to Latin data, Journal of Applied Econometrics 20, 229-251.

[4] Christiano L.J., Eichenbaum M. and C.L. Evans, 1999, Monetary policy shocks: what have we learned and to what end?, in: J.B. Taylor and M. Woodford, eds., Handbook of macroeconomics, (Elsevier, New York).

[5] Cushman, D.O. and T. Zha, 1997, Identifying monetary policy in a small open economy under flexible exchange rates, Journal of Monetary Economics 39, 433-448.

[6] Flood, R.P. and A.K. Rose, 1995, Fixing exchange rates: a virtual quest for fundamentals, Journal of Monetary Economics 36, 3-37. 
[7] Kim, S.,1999, Do monetary policy shocks matter in the G-7 countries? Using common identifying assumptions about monetary policy across countries, Journal of International Economics 48, 387-412.

[8] Kim, S., 2001, International transmission of U.S. monetary policy shocks: evidence from VAR's, Journal of Monetary Economics 48, 33-372.

[9] Kim, S. and N. Roubini, 2000, Exchange rate anomalies in the industrial countries: a solution with a structural VAR approach, Journal of Monetary Economics 45, 561-586.

[10] Leeper, E.M., C.A. Sims and T. Zha, 1996, What does monetary policy do?, The Brookings Papers on Economic Activity 2, 1-48.

[11] Mendoza, E.G., 1991, Real business cycles in a small open economy, American Economic Review 81, 797-818.

[12] Miniane, J. and J.H. Rogers, 2003, Capital controls and the international transmission of U.S. money shocks, Board of Governors of the Federal Reserve System International Finance Discussion Paper 778.

[13] Neumeyer, P.A. and F. Perri, 2005, Business cycles in emerging economies: the role of interest rates, Journal of Monetary Economics 52, 345-380.

[14] Sims, C.A., 1980, Macroeconomics and reality, Econometrica 48, 1-48.

[15] Sims, C.A. and T. Zha, 1998, Bayesian methods for dynamic multivariate models, International Economic Review 49, 949-968.

[16] Uribe, M. and V.Z. Yue, 2003, Country spreads and emerging markets: who drives whom?, NBER Working Paper 10018, forthcoming in Journal of International Economics.

[17] Zha, T., 1999, Block recursion and structural vector autoregressions, Journal of Econometrics 90, 291-316. 


\section{A Data}

The source of data is Datastream. The vector $y_{2}(t)$ includes the Federal Funds rate (USI60B..), the IMF non-fuel commodity dollar-based index (WDI76AXDF) as a measure of world commodity prices, M2 (USI59MBCB) as a measure of the U.S. money stock, real industrial production (USIPTOT.G) as a measure of U.S. real aggregate output and the wholesale price index (USI63...F) as a measure of the U.S. aggregate price level. The vector $y_{1}(t)$ includes the following variables country by country. Chile: the short-term commercial bank loan rate (CLI60P..), the exchange rate (CLI..AE.), real manufacturing production (CLI66EY.F), the consumer price index (CLI64...F). Hong Kong: the 3-month interbank interest rate (HKINTER3), the exchange rate (HKXRUSD.), manufacturing production (HKIPMAN.H), the consumer price index (HKCONPRCF). Korea: the call money rate (KOI60B..), the exchange rate (KOI..AE.), real industrial production (KOI66..CE), the consumer price index (KOI64...F). Malaysia: the call money rate (MYI60B..), the exchange rate (MYI..AE.), real industrial production (MYI66...F), the consumer price index (MYI64...F). Mexico: the 1-month treasury security rate (MXYTC28.), the exchange rate (MXI..AE.), real industrial production (MXINPRODH), the consumer price index (MXI64...F). Philippines: the treasury bill rate (PHI60C..), the exchange rate (PHI..AE.), real manufacturing production (PHI66EY.F), the consumer price index (PHI64...F). Singapore: the money market interest rate (SPI60B..), the exchange rate (SPI..AE.), real industrial production (SPINPROQH), consumer price index (SPI64...F). Thailand: the call money rate (THI60B..), the exchange rate (THI..AE.), real manufacturing production (THMANPRDG), the consumer price index (THI64...F). All data were extracted from Datastream on a monthly basis, except for the series (HKIPMAN.H) and (SPINPROQH) which are available at a quarterly basis and which I interpolated. 


\section{Table 1: The fraction of the variance due to external shocks and U.S. monetary policy shocks}

\begin{tabular}{|c|c|c|c|c|c|c|c|c|c|c|c|c|}
\hline Variable & Source of disturbance & $\begin{array}{l}\text { Horizon } \\
\text { (months) }\end{array}$ & Korea & Malaysia & Philippines & Thailand & Hong Kong & Singapore & Chile & Mexico & $\begin{array}{c}\text { Average, } \\
\text { emerging mkts }\end{array}$ & U.S. \\
\hline \multirow[t]{4}{*}{ Interest rate } & \multirow[t]{2}{*}{ External shocks } & $1-24$ & 34 & 22 & 29 & 23 & 37 & 32 & 20 & 39 & 30 & - \\
\hline & & $25-48$ & 35 & 39 & 42 & 26 & 40 & 37 & 15 & 49 & 35 & - \\
\hline & \multirow{2}{*}{$\begin{array}{l}\text { U.S. monetary policy } \\
\text { shocks }\end{array}$} & $1-24$ & 7 & 3 & 4 & 3 & 5 & 4 & 1 & 4 & 4 & 5 \\
\hline & & $25-48$ & 5 & 3 & 4 & 3 & 3 & 4 & 2 & 4 & 4 & 15 \\
\hline \multirow[t]{4}{*}{ Exchange rate } & \multirow{2}{*}{ External shocks } & $1-24$ & 48 & 55 & 35 & 60 & 25 & 64 & 36 & 48 & 46 & - \\
\hline & & $25-48$ & 60 & 58 & 50 & 67 & 42 & 82 & 56 & 69 & 61 & - \\
\hline & \multirow{2}{*}{$\begin{array}{l}\text { U.S. monetary policy } \\
\text { shocks }\end{array}$} & $1-24$ & 4 & 4 & 3 & 7 & 8 & 4 & 6 & 6 & 5 & - \\
\hline & & $25-48$ & 4 & 5 & 4 & 6 & 12 & 5 & 10 & 5 & 6 & - \\
\hline \multirow[t]{4}{*}{ Price level } & \multirow[t]{2}{*}{ External shocks } & $1-24$ & 36 & 37 & 34 & 36 & 43 & 51 & 39 & 47 & 40 & - \\
\hline & & $25-48$ & 59 & 58 & 51 & 54 & 78 & 81 & 65 & 78 & 66 & - \\
\hline & \multirow{2}{*}{$\begin{array}{l}\text { U.S. monetary policy } \\
\text { shocks }\end{array}$} & $1-24$ & 11 & 8 & 9 & 8 & 7 & 2 & 2 & 6 & 7 & 2 \\
\hline & & $25-48$ & 8 & 20 & 6 & 11 & 6 & 5 & 3 & 5 & 8 & 6 \\
\hline \multirow[t]{7}{*}{ Real output } & \multirow[t]{2}{*}{ External shocks } & $1-24$ & 27 & 31 & 29 & 45 & 50 & 46 & 28 & 32 & 36 & - \\
\hline & & $25-48$ & 33 & 35 & 35 & 56 & 72 & 66 & 47 & 50 & 49 & - \\
\hline & \multirow{2}{*}{$\begin{array}{l}\text { U.S. monetary policy } \\
\text { shocks }\end{array}$} & $1-24$ & 4 & 3 & 7 & 2 & 2 & 9 & 4 & 3 & 4 & 4 \\
\hline & & $25-48$ & 5 & 3 & 6 & 3 & 3 & 16 & 5 & 3 & 6 & 3 \\
\hline & Notes: "External shocks" sta & ands for the & ction of the & ce in a given va & able due to all exter & al shocks jointly. & & & & & & \\
\hline & "1-24" stands for the averas & ge between & e month afte & lock and $24 \mathrm{mo}$ & is after a shock. "2 & $-48 "$ stands for t & average between & 5 months after a & and $48 \mathrm{n}$ & ter a shock. & & \\
\hline & Each row in the column "Av & verage, eme & ng mkts" is t & erage of the ent & s in the same row $i$ & the preceding 8 & olumns. & & & & & \\
\hline
\end{tabular}




\section{Table 2: The impulse responses to a U.S. monetary policy shock, one standard deviation in size.}

\begin{tabular}{|c|c|c|c|c|c|c|c|c|c|c|c|}
\hline Variable & $\begin{array}{l}\text { Horizon } \\
\text { (months) }\end{array}$ & Korea & Malaysia & Philippines & Thailand & Hong Kong & Singapore & Chile & Mexico & $\begin{array}{c}\text { Average, } \\
\text { emerging mkts }\end{array}$ & U.S. \\
\hline \multirow[t]{4}{*}{ Interest rate } & $1-3$ & 0.16 & 0.05 & 0.14 & 0.17 & -0.03 & 0.04 & -0.26 & 0.4 & 0.08 & 0.02 \\
\hline & $1-6$ & 0.2 & 0.07 & 0.13 & 0.28 & -0.05 & -0.003 & -0.04 & 0.95 & 0.19 & 0.02 \\
\hline & $7-18$ & 0.28 & 0.06 & 0.17 & 0.23 & -0.16 & -0.09 & -0.1 & 1.2 & 0.20 & -0.05 \\
\hline & $19-36$ & 0.12 & 0.09 & -0.08 & 0.11 & -0.16 & -0.02 & -0.16 & 0.06 & -0.01 & -0.1 \\
\hline \multirow[t]{4}{*}{ Exchange rate } & $1-3$ & 0.44 & 0.19 & 0.38 & 0.98 & -0.01 & 0.12 & -0.22 & 0.58 & 0.31 & - \\
\hline & $1-6$ & 0.53 & -0.04 & 0.49 & 1 & -0.02 & -0.04 & -0.27 & 1.05 & 0.34 & - \\
\hline & $7-18$ & 0.84 & -0.7 & 0.37 & 0.3 & -0.02 & -0.32 & -0.46 & 2.39 & 0.30 & - \\
\hline & $19-36$ & 0.67 & -0.59 & -0.42 & -0.5 & -0.03 & -0.56 & -0.75 & 1.52 & -0.08 & - \\
\hline \multirow[t]{3}{*}{ Inflation } & $1-6$ & 0.02 & 0.01 & 0.02 & 0.02 & 0.02 & 0.004 & -0.000 & 0.1 & 0.02 & 0.007 \\
\hline & $7-18$ & 0.01 & 0.002 & 0.01 & 0.01 & 0.01 & 0.007 & 0.002 & 0.08 & 0.02 & -0.01 \\
\hline & $19-36$ & -0.004 & 0.004 & -0.003 & 0.01 & 0.01 & 0.003 & -0.002 & -0.04 & -0.003 & -0.005 \\
\hline \multirow[t]{3}{*}{ Real output } & $1-6$ & -0.14 & -0.04 & 0.68 & -0.02 & -0.005 & -0.18 & 0.24 & 0.01 & 0.07 & -0.02 \\
\hline & $7-18$ & -0.54 & 0.04 & 0.44 & -0.06 & -0.05 & -0.34 & 0.4 & -0.24 & -0.04 & -0.13 \\
\hline & $19-36$ & -0.59 & -0.04 & 0.17 & 0.24 & 0.05 & -0.57 & 0.68 & -0.26 & -0.04 & -0.11 \\
\hline
\end{tabular}

Notes: "1-3" stands for the average between one month after a shock and 3 months after a shock. "1-6" stands for the average between the first month after a shock and 6 months after a shock.

"7-18" stands for the average between 7 months after a shock and 18 months after a shock. "19-36" stands for the average between 19 months after a shock and 36 months after a shock.

Each row in the column "Average, emerging mkts" is the average of the entries in the same row in the preceding 8 columns.

Each entry in Table 2 is based on the median of the posterior distribution of a given variable of interest, where the variable of interest is e.g. the impulse response of the interest rate in Korea to a U.S.

The impulse responses are percentage deviations, except that the impulse responses of interest rates are deviations in basis points. 


\section{SFB 649 Discussion Paper Series 2006}

For a complete list of Discussion Papers published by the SFB 649, please visit http://sfb649.wiwi.hu-berlin.de.

001 "Calibration Risk for Exotic Options" by Kai Detlefsen and Wolfgang K. Härdle, January 2006.

002 "Calibration Design of Implied Volatility Surfaces" by Kai Detlefsen and Wolfgang K. Härdle, January 2006.

003 "On the Appropriateness of Inappropriate VaR Models" by Wolfgang Härdle, Zdeněk Hlávka and Gerhard Stahl, January 2006.

004 "Regional Labor Markets, Network Externalities and Migration: The Case of German Reunification" by Harald Uhlig, January/February 2006.

005 "British Interest Rate Convergence between the US and Europe: A Recursive Cointegration Analysis" by Enzo Weber, January 2006.

006 "A Combined Approach for Segment-Specific Analysis of Market Basket Data" by Yasemin Boztuğ and Thomas Reutterer, January 2006.

007 "Robust utility maximization in a stochastic factor model" by Daniel Hernández-Hernández and Alexander Schied, January 2006.

008 "Economic Growth of Agglomerations and Geographic Concentration of Industries - Evidence for Germany" by Kurt Geppert, Martin Gornig and Axel Werwatz, January 2006.

009 "Institutions, Bargaining Power and Labor Shares" by Benjamin Bental and Dominique Demougin, January 2006.

010 "Common Functional Principal Components" by Michal Benko, Wolfgang Härdle and Alois Kneip, Jauary 2006.

011 "VAR Modeling for Dynamic Semiparametric Factors of Volatility Strings" by Ralf Brüggemann, Wolfgang Härdle, Julius Mungo and Carsten Trenkler, February 2006.

012 "Bootstrapping Systems Cointegration Tests with a Prior Adjustment for Deterministic Terms" by Carsten Trenkler, February 2006.

013 "Penalties and Optimality in Financial Contracts: Taking Stock" by Michel A. Robe, Eva-Maria Steiger and Pierre-Armand Michel, February 2006.

014 "Core Labour Standards and FDI: Friends or Foes? The Case of Child Labour" by Sebastian Braun, February 2006.

015 "Graphical Data Representation in Bankruptcy Analysis" by Wolfgang Härdle, Rouslan Moro and Dorothea Schäfer, February 2006.

016 "Fiscal Policy Effects in the European Union" by Andreas Thams, February 2006.

017 "Estimation with the Nested Logit Model: Specifications and Software Particularities" by Nadja Silberhorn, Yasemin Boztuğ and Lutz Hildebrandt, March 2006.

018 "The Bologna Process: How student mobility affects multi-cultural skills and educational quality" by Lydia Mechtenberg and Roland Strausz, March 2006.

019 "Cheap Talk in the Classroom" by Lydia Mechtenberg, March 2006.

020 "Time Dependent Relative Risk Aversion" by Enzo Giacomini, Michael Handel and Wolfgang Härdle, March 2006.

021 "Finite Sample Properties of Impulse Response Intervals in SVECMs with Long-Run Identifying Restrictions" by Ralf Brüggemann, March 2006.

022 "Barrier Option Hedging under Constraints: A Viscosity Approach" by Imen Bentahar and Bruno Bouchard, March 2006.

\section{SFB 649, Spandauer Straße 1, D-10178 Berlin} http:/ / sfb649.wiwi.hu-berlin.de

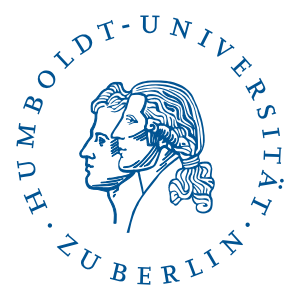


023 "How Far Are We From The Slippery Slope? The Laffer Curve Revisited" by Mathias Trabandt and Harald Uhlig, April 2006.

024 "e-Learning Statistics - A Selective Review" by Wolfgang Härdle, Sigbert Klinke and Uwe Ziegenhagen, April 2006.

025 "Macroeconomic Regime Switches and Speculative Attacks" by Bartosz Maćkowiak, April 2006.

026 "External Shocks, U.S. Monetary Policy and Macroeconomic Fluctuations in Emerging Markets" by Bartosz Maćkowiak, April 2006. 